\title{
Penerapan Sistem Komposisi Serial Pada "El Polifemo de Oro" untuk Gitar Karya Reginald Smith Brindle (1917-2003)
}

\author{
Malik Hasanudin Aulia ${ }^{1}$ dan Andre Indrawan ${ }^{2}$ \\ 1,2,Jurusan Musik Fakultas Seni Pertunjukan Institut Seni Indonesia Yogyakarta
}

\begin{abstract}
The work of El Polifemo de Oro is one of the classical guitar repertoire which using the serialism in its compotition. The work was created by Reginald Smith Brindle a British composer. The author uses a Theoretical method of research into research, using many of theories to analyze the work. Studies indicate that work was proven to be using "free serialism system".
\end{abstract}

Keywords: El Polifemo de Oro; Reginald Smith Brindle; Serialism

\begin{abstract}
Abstrak
Karya El Polifemo de Oro merupakan salah satu repertoar gitar klasik yang menggunakan penerapan sistem serial pada komposisinya. Karya tersebut diciptakan oleh Reginald Smith Brindle seorang komponis dari Inggris. Penulis menggunakan metode Teoritikal dalam melakukan penelitian, yaitu menggunakan suatu teori untuk menganalisis karya tersebut. Di dalam skripsi ini dituliskan mengenai penerapan sistem serial pada El Polifemo de Oro, teoriteori sistem serial, dan macam-macam sistem serial. Hasil penelitian menunjukkan bahwa El Polifemo de Oro menggunakan sistem serial campuran atau biasa disebut free serialism sistem.
\end{abstract}

Kata kunci: El Polifemo de Oro; Polifemo; Reginald Smith Brindle; Serialism

\section{Pengantar}

Seiring berkembangnya jaman, komposisi gitar klasik mengalami perkembangan, baik dari penggunaan sistem tangga nada, penerapan harmoni, sampai pada pengolahan timbre instrumen tersebut. Dimulai pada jaman Renasains yang menggunakan sistem modal berubah menjadi sistem tonal pada jaman Barok dan kemudian berubah menjadi sistem atonal pada awal abad ke-20. Hal tersebut berpengaruh pada para komposer gitar klasik untuk juga menggunakan sistem atonal pada karya-karyanya.

Pada awal abad ke-20, banyak komposer gitar klasik yang membuat karya komposisi gitar klasik dengan menggunakan sistem serial ini. Misalnya, Reginald Smith Brindle lagu "El Polifemo de Oro" (1956 kemudian direvisi pada 1981), Richard Rodney Bennet "Impromptus" (1968), Hans Werner Henze "Royal Winter Music" (1976 bagian pertama, 1979 bagian kedua). Awal diperkenalkannya karya musik dengan sistem serial pada awal abad ke-20 oleh Arnold Schoenberg, terjadi pro kontra dan banyak tanggapan serta kritik yang terlontar untuk sistem musik ini. Musisi dan kritikus beranggapan bahwa Schoenberg telah menggulingkan sistem tonalitas. Serialisme sering mengarah pada kesan ketidak manusiawian, dalam pengertian musik tidak bisa difahami dan keteraturannya sama sekali tidak bisa terdengar, dalam hal ini 
musik serial dianggap tidak musikal dan sebagainya namun pada akhirnya musik serial dapat diterima dan diterapkan oleh para komponis sehingga dapat mewarnai perkembangan musik di dunia. (Mark 2009: 16)

Penulis tertarik dan bermaksud untuk mengkaji dan meneliti lebih dalam mengenai penerapan sistem serial pada instrumen gitar klasik karya "El Polifemo de Oro" yang menggunakan sistem serial. Alasan penulis memilih karya ini adalah karya ini memiliki sistem serial yang berbeda yang mana merupakan penggabungan dari sistem atonal non serial. Dalam penelitian ini penulis menggunakan metode penelitian kualtitatif dengan metode kontekstual analitikal. Menurut Watanabe (1967) metode analitikal sendiri dilakukan dengan cara mengambil dan merekonstruksi subjek untuk mengetahui bagaimana subjek itu berfungsi. Langkah-langkah yang akan penulis tempuh yang pertama adalah mencari teori yang bersangkutan dengan apa yang akan diteliti dengan studi pustaka. Yang kedua penulis akan menganalisis sistem serial dari El Polifemo de Oro dengan teori- teori yang ada. Dan yang kedua sekaligus terakhir penulis akan menarik kesimpulan dari hasil yang diperoleh.

\section{Pembahasan}

Tinjauan Teoritis Sistem Serialisme 12 Nada dan Tinjauan Historis Reginald Smith Brindle dan El Polifemo de Oro Serialism atau serialisme merupakan sistem pembuatan komposisi yang diciptakan pada tahun 1950-an oleh Arnold Schoenberg yang didasarkan pada deret 12 nada yang disusun dari pitch class (bukan pitches). (Mack, 2009: 7). Sistem serialisme ini diciptakan dengan alasan untuk memaksimalkan pengeluaran nada kromatis dalam suatu komposisi musik, yang mana dalam sebuah tone row tiap pitch class yang sudah keluar dalam deret tidak boleh keluar lagi sebelum nada yang lain muncul. Serialisme juga merupakan sebuah gebrakan baru untuk menggulingkan tonalitas dan berkembang luas berkembang luas pada era post-tonal. Hal ini merupakan konsepsi dasar serialisme klasik yang diciptakan oleh Schoenberg.

Era post-tonal ini terdapat beberapa konsep dasar pada sistem penerapan nadanadanya terutama yang terjadi pada sistem serial 12 nada, yang pertama adalah oktaf equivalen. Ada sesuatu yang berbeda atau spesial pada oktaf dalam ranah post-tonal, pitch dipisahkan oleh satu atau lebih oktaf yang biasanya memiliki kesan yang sama dalam satu rasa equivalensi. (Straus, 2005: 1). Equivalensi ini ditanggapi pada teori musik barat yang kita anut saat ini dengan memberikan nama pitch yang sama. Semisal nada A pada middle $\mathrm{C}$, akan sama namanya degan oktaf yang lebih tinggi atau oktaf yang lebih rendah. Perlu diketahui bahwa equivalensi berbeda dengan identitas nada.

Kedua adalah pitch class atau sebuah tone dengan nada tertentu berbeda dengan dengan pitch class atau grup dari pitch dengan nada yang sama. (Straus, 2005: 3). Hal ini berarti bahwa nada yang muncul dalam oktaf yang berbeda masih merupakan anggota pitch class yang sama, begitu juga dengan enharmonis (C-B\#-D). Pada umumnya pitch class dilambangkan dengan integer (bilangan bulat) 0-11. Integer tersebut berfungsi mempresentasikan beberapa relasi musikal. Tabel di bawah merupakan penjelasaan untuk penggunaan integer:

Tabel 1. Integer dan Pitch Class Sumber: Straus, 2005: 5

\begin{tabular}{|c|c|}
\hline Nama Integer & Konten Pitch Class \\
\hline 0 & $\mathrm{~B} \neq, \mathrm{C}, \mathrm{D}$ \\
\hline 1 & $C *, D b$ \\
\hline 2 & $C *, D, E b$ \\
\hline 3 & $\mathrm{D} \neq, \mathrm{Eb}$ \\
\hline 4 & $\mathrm{D} \boldsymbol{*}, \mathrm{E}, \mathrm{Fb}$ \\
\hline 5 & $\mathrm{E} *, \mathrm{~F}, \mathrm{G}$ \\
\hline 6 & $\mathrm{~F} \neq, \mathrm{G} b$ \\
\hline 7 & $\mathrm{~F} \boldsymbol{*}, \mathrm{G}, \mathrm{A} \boldsymbol{t}$ \\
\hline 8 & $G *, A b$ \\
\hline 9 & $\mathrm{G} * \mathrm{~A}, \mathrm{~B} * \boldsymbol{b}$ \\
\hline $\mathrm{T}$ (Ten) & $\mathrm{A} \neq, \mathrm{Bb}, \mathrm{Cb}$ \\
\hline $\mathrm{E}$ (Eleven) & $\mathrm{A} * \mathrm{~B}, \mathrm{Cb}$ \\
\hline
\end{tabular}


Ketiga adalah tone row atau deret nada. Dalam sistem serial, deret nada / deret dasar merupakan susunan dari dua belas nada kromatis yang setiap nada hanya muncul satu kali. Deret nada memiliki empat bentuk dasar, yaitu:

1. Prime $(\mathrm{P})$, adalah deret utama atau deret asli yang pertama kali muncul pada sebuah komposisi yang menggunakan sistem serial.

2. Inversions (I), adalah bentuk utama dengan interval terbalik.

3. Retrogade (R), adalah bentuk utama dengan susunan terbalik.

4. Retrograde Inversi (RI), adalah deret inversion yang diretrograde.

Untuk teori sistem serial, musik atonal mengarah pada musik yang benarbenar tidak dibentuk oleh sistem komposisi tradisional (tonal), begitu juga dengan sistem modal atau sistem tangga nada mayor dan minor. (Brindle, 1966: 11). Musik atonal pada awalnya dianggap sebagai musik yang tidak manusiawi, bahkan dikatakan "bukan musik". Walaupun pada akhirnya sistem atonal diterima dan diakui sebagai musik seni.

Dalam sistem serial tradisional, setiap pitch class hanya keluar satu kali sebelum kesebelas pitch class lainnya muncul dalam satu deret seri. Kemudian grup notasi yang muncul juga berlaku demikian, grup notasi tersebut boleh muncul kembali pada deret berikutnya setelah satu deret selesai. Untuk menghindari kekauan, dalam pengolahan bentuk prime deret seri diberlakukan teknik retrograde, invertion, dan retrograde inversion seperti yang telah dijelaskan pada konten deret nada di atas. Kemudian untuk menghindari kekauan juga digunakan subset, subset adalah rangkaian dari dua sampai sebelas nada yang masuk dalam deret dasar yang muncul sebagian dalam sebuah karya.

Biografi Reginald Smith Brindle, Brindle lahir pada 5 Januari 1917 dan meninggal pada 9 September 2003 di
Cuerdon, Lanchasire dan merupakan seorang komponis dari Inggris. Dia mulai belajar piano pada usia 6 tahun, meskipun semangat untuk bermusiknya pertama kali tumbuh ketika ia mendengarkan seorang master di sekolahnya memainkan instrumen flute. Brindle kemudian berpindah instrumen klarinet, ia belajar klarinet di sekolahnya dengan J V Abrams sebagai gurunya. Kemudian ia berpindah lagi untuk bermain instrumen saxophone ketika ia meninggalkan sekolahnya pada tahun 1933 karena di bawah tuntutan orang tuanya untuk sekolah arsitektur. Brindle juga bermain gitar, dia pernah memenangkan hadiah gitar dalam "Melody Maker band contest". (Wright, 2004: 1).

Meskipun Brindle menulis komposisinya pada berbagai macam instrumen, namun mungkin ia lebih dikenal karya gitarnya, terutama El Polifemo de Oro (1956) yang ditulis untuk Jullian Bream, juga karya Five Sonatas (1948, 1976, 1978, 1979), Variants on Two Theme of J.S. Bach (1970), Memento in Two Movements (1973), November Memories (1974), Four Poems of Garcia Lorca (1975), Do Not Go Gentle... (1979), Preludes and Fantasies (1980), dan The Prince of Venosa (1994). Ia juga memilik satu karya opera, The Death of Antigone yang dikonserkan pertama kali pada 1971.

Karya El Polifemo de Oro, El Polifemo de Oro ditulis pada 1956 dan direvisi pada tahun 1981. Di dalam edisi revisi, Brindle memperpanjang semua bagiannya. Hal ini bertujuan untuk mencapai pemenuhan yang lebih tinggi dari konsep aslinya. Pertama kali karya ini dikonserkan oleh Julian Bream pada tahun 1958 pada Adelbrurgh Festival. Karya ini terinspirasi oleh syair karangan Garcia Lorca yang bereferensi pada gitar, khususnya pada 2 syair Adivinanza de la Guitara dan Las Seis Cuerdas.

Analisis Penerapan Sistem Komposisi Serial Pada "El Polifemo De Oro" Untuk Gitar Karya Reginald Smith Brindle (19172003) 
Karya El Polifemo de Oro terdiri dari 4 gerakan, yaitu Gerakan 1 (Ben Adagio), Gerakan 2 (Allegretto), Gerakan 3 (Largo), dan Gerakan 4 (Ritmico e Vivo). Ke-empat gerakan tersebut memiliki keunikan tersendiri, baik dari pengolahan timbre, ritmis, dinamika, dan ekspresi yang berbedabeda. Karya yang ditulis oleh penulis di sini menggunakan edisi revisi. Revisi tersebut dilakukan oleh Brindle dengan alasan mengembangkan konsep-konsep lain yang belum selesai pada versi originalnya.

Penyusunan matrix serial dalam karya El Polifemo de Oro dapat kita buat dengan cara mengetahui bentuk prime pada awal karya yang menjadi ciri khas dari karya yang menerapkan sistem serial dalam penyusunan komposisinya. Bentuk prime dari karya tersebut adalah P4 (485TE2609317). Diolah dari bentuk prime dan dengan metode yang telah dijelaskan pada tinjauan teori di atas maka dapat kita ketahui bahwa matriks dalam karya El Polifemo de Oro adalah sebagai berikut:

\begin{tabular}{|c|c|c|c|c|c|c|c|c|c|c|c|}
\hline 4 & 8 & 5 & $\mathrm{~T}$ & $\mathrm{E}$ & 2 & 6 & 0 & 9 & 3 & 1 & 7 \\
\hline 0 & 4 & 1 & 6 & 7 & $\mathrm{~T}$ & 2 & 8 & 5 & $\mathrm{E}$ & 9 & 3 \\
\hline 3 & 7 & 4 & 9 & $\mathrm{~T}$ & 1 & 5 & $\mathrm{E}$ & 8 & 2 & 0 & 6 \\
\hline $\mathrm{T}$ & 2 & $\mathrm{E}$ & 4 & 5 & 8 & 0 & 6 & 3 & 9 & 7 & 1 \\
\hline 9 & 1 & $\mathrm{~T}$ & 3 & 4 & 7 & $\mathrm{E}$ & 5 & 2 & 8 & 6 & 0 \\
\hline 6 & $\mathrm{~T}$ & 7 & 0 & 1 & 4 & 8 & 2 & $\mathrm{E}$ & 5 & 3 & 9 \\
\hline 2 & 6 & 3 & 8 & 9 & 0 & 4 & $\mathrm{~T}$ & 7 & 1 & $\mathrm{E}$ & 5 \\
\hline 8 & 0 & 9 & 2 & 3 & 6 & $\mathrm{~T}$ & 4 & 1 & 7 & 5 & $\mathrm{E}$ \\
\hline $\mathrm{E}$ & 3 & 0 & 5 & 6 & 9 & 1 & 7 & 4 & $\mathrm{~T}$ & 8 & 2 \\
\hline 5 & 9 & 6 & $\mathrm{E}$ & 0 & 3 & 7 & 1 & $\mathrm{~T}$ & 4 & 2 & 8 \\
\hline 7 & $\mathrm{E}$ & 8 & 1 & 2 & 5 & 9 & 3 & 0 & 6 & 4 & $\mathrm{~T}$ \\
\hline 1 & 5 & 2 & 7 & 8 & $\mathrm{E}$ & 3 & 9 & 6 & 0 & $\mathrm{~T}$ & 4 \\
\hline
\end{tabular}

Matriks Deret Seri El Polifemo de Oro

Cara membaca matriks tersebut adalah dari kiri ke kanan merupakan bentuk prime $(\mathrm{P})$, kanan ke kiri adalah retrograde (R), atas ke bawah adalah inversion (I), bawah ke atas adalah retrograde inversion (RI). Contoh, deret 514ET7390682 merupakan deret inversion 5 (I5), Kemudian deret 93174T256E80 adalah deret retrograde inversion 0 (RI0), dan deret T460395218E7 adalah deret retrograde 7 (R7).

Analisis penerapan sistem komposisi serial pada Gerakan 1 (Ben Adagio) adalah Brindle menggunakan deret P4 (485TE2609317) pada awal karya tersebut. Deret tersebut muncul pada birama pertama dan kedua secara lengkap. Kemudian deret berikutnya yang muncul adalah I0 (08E652T47139) dengan dua belas nada penuh. Dua nada awal memiliki interval 4 dalam semitone atau dalam musik tonal disebut dengan interval mayor 3. Hal ini memberikan kesan tonal yang muncul untuk pertama kalinya karena merupakan interval disonan dalam musik atonal.

Deret berikutnya yang muncul berupa subset dari RI0 (93174T2) dengan format septachord yang muncul pada birama 5 ketukan kedua syncope. Kemudian pada birama 6 ketukan pertama triol kedua muncul subset I0 (2T47139) dengan format septachord. Pada kasus ini terjadi elusi pada akhir deret RIO dan awal I0 karena ke lima nada awal deret I0 sudah muncul atau dibunyikan pada akhir RI0.

Birama berikutnya muncul femona baru, yaitu keluarnya susunan nada yang tidak masuk dalam deret dasar serial namun masih dalam kesan atonal. Hal ini yang menjadikan komposisi El Polifemo de Oro merupakan karya serial bebas yang bisa dikatakan sebagai serial campuran. Brindle memasukkan nada-nada non serial dalam karya ini pada konsep serialnya. Nada-nada tersebut dimaksudkan sebagai penghubung pada deret berikutnya yang muncul untuk menghilangkan kesan kaku pada sistem serial tradisional.

Setelah fenomena tersebut, muncul deret seri sebagai subset RP4 (7139) yang berbentuk tetrachord yang masih dalam frase yang sama. kemudian disusul dengan munculnya subset I0 (2T4713) dengan format 
hexachord. Pengolahan timbre pada frase tersebut dimulai dengan pizzicato dengan dinamik crescendo pada figur awal yang diakhiri dengan timbre normal yang divibrasi. Hal ini memunculkan kesan klimaks pada bagian tersebut. Kemudian pada birama berikutnya, pengolahan dinamik menjadi ekspresif diolah dengan crescendo - decrescendo, dan pada akhir frase disusun dengan nada yang rapat ditutup dengan fermata.

Birama berikutnya muncul subset I0 (08E6) berbentuk tetrachord yang kemudian disusul oleh pentachord subset RP4 (71390), trichord subset P2 (890) dan trichord subset P5 (T42). Kemudian pada akhir frase muncul nada yang tidak masuk ke dalam deret dasar, ditutup dengan empat nada yang berbentuk akor dan dimainkan dengan teknik arpeggio. Pada awal bagian frase tersebut tempo kembali ke a tempo setelah sebelumnya menemui klimaks yang ditutup degan fermata.

Ending gerakan 1 muncul deret RP4 (62ET584) berbentuk septachord, kemunculan septachord ini merupakan lanjutan dari pentachord yang muncul pada deret sebelumnya. Dengan hal tersebut, RP4 muncul secara penuh walaupun telah keluar nada-nada dari deret sebelumnya yang muncul sebelum RP4 muncul secara penuh. Pengolahan ritmik pada ending gerakan 1 tersebut memunculkan kesan melebar. Pengolahan dinamik dibangun naik perlahan kemudian diturunkan perlahan hingga pada akhirnya terkesan menghilang. Hal tersebut dipertegas dengan keterangan tanda dinamik crescendo hingga ke forte yang juga menggunakan aksen sebelum sampai pada puncak tensi dengan menggunakan sforzando.

Kemudian penurunan tensi diperjelas dengan keterangan yang tertulis yaitu poco rall. e dim. yang berarti sedikit diperlambat dan dipelankan volume suaranya secara perlahan. Kesan volume suara yang menghilang juga terdapat pada nada terahir yang dimainkan dengan timbre harmonik. Keterangan atau tanda $1 \mathrm{~m} 30$ merupakan keterangan waktu permainan, yaitu bagian ini kira-kira dimainkan kurang lebih selama satu menit tiga puluh detik.

Gerakan 2 merupakan gerakan yang cenderung cepat, ditandai dengan tanda tempo allegretto yang berasal dari bahasa Italia berarti tempo cepat. Allegretto sendiri merupakan tempo yang berada diantara tempo andante dan allegro. Pada bagian ini, tema utama cenderung berkesan seperti arpeggio. Deret seri yang muncul pada awal birama adalah P9 (91T347E52860) yang muncul dua belas nada lengkap. Kemunculan nada pertama P9 berada pada nada ke-2 birama 1 pada singkup ketukan pertama. Keunikan pada gerakan ini adalah nada bass yang berkesan singkup. Pada awal gerakan 2, pengolahan dinamik cukup datar, yaitu mezzoforte.

Nada terakhir dalam deret P9 (91T347E52860) terletak pada awal frase berikutnya, yaitu frase yang berbeda dari sebelas nada yang lain. Peletakan nada yang masuk dalam deret seri juga sangat variatif, tidak selalu pada jalur bass atau nada tingginya. Deret pertama muncul pada bass. Kemudian deret ke-2 sampai ke-5 berada pada nada tinggi begitu juga dengan nada berikutnya yang tidak selalu pada jalur yang sama.

Deret berikutnya yang muncul ialah deret I5 (514ET7390682). Hal yang aneh pada deret ini adalah kemunculan nada 1 yang muncul mendahului nada 5, akan tetapi pada kesepuluh nada lainnya muncul secara urut namun nada 1 tidak muncul lagi sebelum sepuluh nada lain muncul dan hanya muncul sekali pada awal deret seri. Hal tersebut disebut dengan permutasi, yaitu semisal deret dasar seri 123456, kemudian keluar lagi diwakili dengan susunan figur 132456, 234651, dan sebagainya. (Leon Stein, 1979: 8). Pengolahan dinamik mulai terjadi pada deret ini, yaitu terjadinya gradasi dari crescendo decrescendo. Kemudian pada akhir deret 
ditutup dengan trichord yang membentuk akor.

Pada ending bagian pertama gerakan kedua sebelum kembali pada repetisi awal, muncul octachord subset dari P4 (TE2609317). Dua nada terakhir pada deret ini merupakan nada tertinggi, yang kemudian disusul oleh sebuah motif yang tidak termasuk dalam deret seri manapun. Kemunculan motif tersebut mengandung empat susunan dua nada terakhir dengan interval 6 atau diminished 5 yang bergerak secara paralel. Motif tersebut berperan sebagai cadenza.

Pada langkah berikutnya adalah repetisi dari awal bagian kemudian menuju kamar dua. Deret seri yang muncul juga sama, namun ketika masuk pada kamar dua, I5 (514ET7390682) muncul secara lengkap dengan format yang berbeda yaitu tetap dengan arpeggio seperti motif pada tema utama, bukan disusun oleh sederetan cadenza. Pengolahan dinamik pada bagian ini variatif, yaitu dengan crescendodecrescendo yang kemudian disusul dengan tensi yang dibangun naik perlahan. Hal ini ditandai dengan tanda dinamik cresc. poco a poco yang berarti volume suara dinaikkan sedikit demi sedikit. Pengolahan timbre juga variatif, hal ini terjadi dengan olahan ponticello - natural yang dibuat secara silih berganti. Puncak olahan dinamik dan timbre berlangsung sampai pada birama dan deret berikutnya, ditandai dengan dinamik forte kemudian fortissimo lalu crescendo yang pada nada terakhirnya sforzando. Dalam timbre muncul ruvido pada dinamik forte, ruvido sendiri berarti berkesan kasar.

Pada bagian coda, muncul permutasi deret I5 (514ET7390682) dengan susunan deret 4ET790368251. Kemunculan nada integer 1 masuk pada frase selanjutnya yang kemudian disusul dengan kemunculan grup notasi diminished yang merupakan retrograde dari grup notasi diminished pada bagian sebelum kembali ke bagian awal.
Grup notasi dimimished tersebut merupakan jembatan untuk menuju deret terahir dalam gerakan ini. Pengolahan dinamik bagian ini sangat menarik, yaitu dinamik diawali dengan fortissimo kemudian mendadak mezzo forte yang kemudian dinaikkan secara perlahan (crescendo) sampai pada dinamik forte disusul dengan penggunaan aksen (marcato) dan dinaikkan perlahan sampai pada bagian fermata.

Deret yang muncul tereakhir pada gerakan 2 adalah subset P9 (91T347) berbentuk hexachords. Merupakan diminusi deret P9 pada awal gerakan dimulai, namun dalam subset P9 yang muncul pada akhir bagian dimulai dengan akor dan ditutup oleh akor dengan teknik arpeggio. Pengolahan timbre pada akhir gerakan tersebut sangat variatif, yaitu penggunaan timbre natural dan timbre ponticello secara bergantian dalam tiap figur. Kemudian pada akhir bagian terkesan klimak, hal ini ditandai dengan gerakan tersebut ditutup oleh kadensial akor yang sama dengan dinamik fortissimo kemudian sforzando disertai dengan penekanan aksen dan menggunakan teknik strumming arpeggio dengan menggunakan kuku jari i atau telunjuk. Keterangan 2m15 merupakan keterangan bahwa gerakan ini dimainkan kurang lebih 2 menit 15 detik.

Gerakan 3 merupakan gerakan dimainkan dengan tempo lambat. Hal ini ditandai dengan keterangan largo yang berarti tempo yang sangat lambat. Biasanya largo jugan menjadi sebuah nama untuk gerakan lambat pada sebuah karya musik. Ekspresi yang digunakan dalam gerakan ini adalah ben cantato yang berarti benar-benar bernyanyi. Cantato sendiri berarti sebuah karya seni musik vokal yang disertai dengan iringan, jadi pada gerakan 3 dimainkan dengan kesan benar benar bernyanyi seperti pada musik vokal yang disertai dengan iringan. Deret seri yang muncul pada awal gerakan 3 adalah I5 (514ET7390682). Deret 
tersebut muncul secara penuh, diawali dari birama 1 ketukan pertama sampai dengan birama 3 ketukan pertama. Kemudian deret berikutnya yang muncul adalah deret I0 (08E652T47139) pada birama 2 ketukan kedua. Kemunculan dua nada pertama dalam deret I0 adalah nada yang telah muncul pada deret sebelumnya, hal ini disebut dengan elusi.

Pada Gerakan 3 tersebut, Brindle menempatkan notasi deret serinya tidak selalu terdapat pada alur melodi yang terkesan seperti musik vokal, namun dia juga menyelipkan notasi untuk melengkapi deret pada iringannya. Hal tersebut dapat kita lihat bahwa alur melodi berada pada garis lengkung dan notasi dengan tangkai atas, sedangkan alur iringan berada pada jalur bawah dengan notasi tangkai ke bawah juga. Kemudian deret belum tentu selesai dalam satu motif, namun bisa kemudian disisipkan dalam motif setelahnya. Pengolahan dinamik pada awal gerakan ini masih datar, yaitu pada dinamik mezzo forte. Hanya saja pada akhir dari I0 ada penaikan dinamik yang ditandai dengan keterangan crescendo. Peran crescendo adalah memberikan kesan lebih dramatis untuk menuju ke deret berikutnya.

Deret berikutnya yang muncul adalah deret I5 (514ET7390682) yang muncul secara penuh. Deret tersebut muncul setelah repetisi notasi integer 139 yang merupakan trichord subset dari I0 yang berperan menjadi jembatan. Keluarnya awal deret nada juga tidak berada pada ketukan berat, namun berada pada ketukan kedua triol seperenambelasan yang ada pada ketukan atas juga.

Kemudian setelah deret I5, muncul deret P9 (91T347E52860) yang diolah dengan permutasi. Hal ini ditandai dengan kemunculan nada integer $\mathrm{T}$ yang muncul pada deret nada terakhir. Susunan deret nada menjadi (91347E52860T). Setelah deret tersebut muncul, pada akhir bagian A gerakan 3 muncul subset 19 yang berperan sebagai cadenza. Figur pada akhir frase memberikan kesan ritmikal yang ditarik-ulur pada, yaitu ritmik yang disusun secara lebih rapat dan kemudian dikendorkan kembali. Kejadian tersebut didukung juga dengan pengolahan dinamik yang dibuat naik perlahan kemudian diturunkan perlahan. Hal tersebut membuat kesan dalam frase menjadi lebih dramatis. (lihat notasi dalam sukat 5/4 ketukan 2 sampai sukat $4 / 4$ ketukan ke 3).

Kemudian birama selanjutnya merupakan repetisi dari awal gerakan 3 . Deret yang muncul adalah I5, I0, I5, dan P9. Namun dalam P9 yang muncul pada repetisi ini berbeda dengan P9 pada deret yang telah dijelaskan di atas. Dalam bagian ini, P9 muncul dengan akhiran deret yang berbeda dan kemunculannya juga tidak lengkap, hanya berupa subset. Subset yang muncul adalah subset P9 (91T347E) berbentuk septachord. Pengolahannya pun dengan menggunakan permutasi juga sehingga susunannya menjadi 91347ET. Untuk pengolahan dinamik dan ritmik hampir sama dengan P9 yang muncul sebelumnya, namun dalam akhir frase kesan melebar bisa dirasakan karena susunan ritmik yang melebar dan didukung dengan dinamik yang semakin mengecil dari meno forte (sedikit keras) kemudian diturunkan perlahan (decrescendo) sampai tanda koma $($ ).

Deret yang muncul pada birama berikutnya adalah deret I5 (514ET7390682) dengan kemunculan 12 nada penuh. Kemunculan deret ini merupakan pengembangan dari tema awal. Dua figur dalam motif yang menjadi tema awal diolah dengan cara dinaikkan atau diturunkan oktafnya dan pada figur kedua terjadi ritmik yang lebih rapat serta ada penambahan nada. Pengolahan imitasi nada dalam motif tersebut adalah nada dengan teknik harmonik dan menaikkan atau menurunkan nadanya satu oktaf. Kemudian peran dari nada tambahan setelah nada akhir deret 
keluar merupakan jembatan untuk menuju deret berikutnya.

Pada birama berikutnya, deret yang muncul adalah I0 (08E652T47139). Kemunculan subset 10 nada awal adalah runtut, setelah kemunculan 10 nada tersebut, muncul semifrase atau motif lain yang nadanada tersebut tidak masuk pada deret dasar, semifrase tersebut berfungsi sebagai interlude. Kemudian setelah kemunculan interlude baru muncul subset 2 nada akhir dari deret I0 dan deret I0 telah muncul secara utuh.

Deret seri yang muncul terakhir dalam gerakan ini adalah RI0 (93174T256E80). Kemunculan deret RI0 pada subset awal merupakan echo dari I0 yang diolah secara terbalik (retrograde). Deret RI0 tersebut muncul dengan olahan permutasi, sehingga urutan nada menjadi (9314T2560E8). Bagian dari deret terakhir yang muncul merupakan bagian coda dari gerakan ke-3. Kemunculan nada-nada yang tidak masuk dalam deret dasar merupakan bagian dari rangkaian coda. Kemudian pada akhir coda tersebut muncul sebuah cadenza yang merupakan satu akor dimainkan dengan pengoalahan ritmik yang melebar. Hal ini disebut dengan ritmical cadens.

Gerakan ke empat merupakan gerakan yang terakhir dalam karya ini. Brindle memadukan sistem komposisi serial dengan memasukkan idiomatik musik Rock. Hal tersebut dapat kita ketahui dari pengolahan ritmik yang berkesan hidup (ritmico e vivo).

Penerapan sistem serial yang muncul hanya beberapa deret saja, selain itu merupakan kumpulan-kumpulan melodi dari nada di luar deret dasar. Nada-nada tersebut memiliki berbagai macam fungsi, ada yang berfungsi sebagai frase utama, interlude, dan kadensial. Hal ini memperjelas Brindle menggabungkan teknik komposisi serial dan atonal non serial dalam penerapannya dalam karya El Polifemo de Oro.

Deret pertama yang muncul adalah P9 (91T347E52860). Muncul dua belas nada penuh dengan permutasi integer 91T437E52860. Pola ritmik pada awal bagian tersebut merupakan tema ritmikal yang selanjutnya akan muncul kembali pada motif-motif berikutnya baik sebagai repetisi maupun diolah dengan pengolahan motif yang berbeda. Pada awal bagian ini, pengolahan dinamik dan timbre masih terkesan polos. Pengolahan dinamik pada notasi di atas adalah mezzo forte. Tidak ada perubahan dinamik pada awal bagian tersebut. Kemudian pengolahan timbre diolah dengan ponticello dan tidak ada perubahan olahan timbre.

Setelah 12 nada dalam deret P9 muncul, deret I5 (514ET7390682) muncul menyambut. Sebelas subset dari I5 muncul hampir runtut, namun nada terakhir dalam deret I5 yaitu nada D (2) muncul agak jauh dari kesebelas subset lainnya. Nada D (2) muncul pada bagian frase yang lain. Setelah 11 nada subset dari I5 di atas muncul, muncul frase baru yang nada-nadanya tidak masuk dalam deret dasar serial, namun ada penyisipan nada terakhir dari deret I5 yaitu D (2) yang menjadikan deret I5 menjadi lengkap. Dalam frase tersebut terdapat kesan figur atau motif yang diolah dengan cara sekuen, namun terdapat penyempitan ritmis dan interval dalam susunannya.

Pada birama berikutnya, muncul motif non serial yang berbeda dari motif sebelumnya, namun hal ini merupakan lanjutan pengolahan frase nada non serial pada frase sebelumnya atau bisa dikatakan masih dalam satu rangkaian frase tanyajawab (anteseden-konsekuen). Kedua frase tersebut berlaku sebagai jembatan menuju deret seri berikutnya. Di dalam frase tersebut terdapat motif melodi dengan susunan nada yang hampir menyerupai tangga nada minor pentatonis seperti yang lazim atau sering 
digunakan pada musik rock, namun tetap tidak memiliki tonalitas.

Hal yang terjadi berikutnya adalah kesan repetisi dari awal gerakan dimulai namun dengan pengolahan yang berbeda. Terjadi beberapa pengurangan atau penambahan nada dalam olahannya. Seperti yang terjadi pada deret berikutnya yang muncul, yaitu subset dari P9 (347E52860). P9 muncul dengan bentuk yang tidak lengkap, tidak seperti yang terjadi pada awal gerakan. Setelah kemunculan subset dari P9, disusul oleh keluarnya I5 (514ET7390682) seperti yang terjadi pada awal gerakan. Terdapat perbedaan antara I5 yang muncul saat ini dengan I5 yang muncul pada awal gerakan. Perbedaan tersebut terdapat pada nada terakhir deret I5 muncul lebih rapat dibanding dengan I5 pada bagian awal gerakan.

Kemunculan I5 tersebut merupakan kemunculan deret serial terakhir yang muncul pada gerakan dan karya ini. Setelah hal itu terjadi, Brindle mengolah karyanya dengan nada-nada atonal non-serial dengan berbagai macam fungsi. Seperti yang terjadi pada birama berikutnya, masih dalam kesan repetisi dari awal gerakan seperti yang sudah dijelaskan seperti yang tertera pada paragraf sebelumnya.

Birama berikutnya juga masih terdapat pengolahan yang sama seperti birama sebelumnya, yaitu masih dalam penambahan atau pengurangan nada dan ritmis atau grup ritmis. Perbedaan yang mencolok terdapat pada akhir bagian, yaitu pada birama terakhir sebelum repetisi ke awal bagian (kamar 1). Pada akhir frase tersebut motif yang tadinya muncul dengan pengurangan nada terakhir kini muncul dengan nada yang utuh, menjadikannya sekuen figur secara utuh serta dengan ritmis yang lebih rapat. Hal ini mengakibatkan kesan mengejutkan.

Pada awal bagian B (setelah memasuki kamar 2), memiliki kesan mengimitasi tema awal namun hanya diambil pada figur pertamanya dan mengambil pokok-pokok grup ritmis yang sering diulang. Hal ini merupakan jawaban dari ritmico e vivo, keterangan yang menerangkan bahwa bagian ini merupakan pengembangan yang sifatnya menonjolkan masalah ritmikal. Pengulangan grup ritmis tersebut sebenarnya terjadi dalam setiap gerakan dalam karya El Polifemo de Oro walaupun diolah dengan gaya yang berbeda maupun dengan jumlah nada, bentuk, dan nada yang berbeda.

Selanjutnya, muncul motif berbentuk grup ritmis seperti yang terjadi pada birama sebelumnya namun disusul dengan munculnya beberapa motif melodi satu suara. Kemudian muncul motif akor yang diolah dengan menggunakan ritmik yang berbeda dari grup ritmis sebelumnya namun memiliki esensi yang sama, yaitu menonjolkan ritmis seperti yang telah dijelaskan pada paragraf sebelumnya.. Brindle menyisipkan tanggan nada A minor pentatonis dan $G$ minor pentatonis dalam frase melodi pada notasi di atas. Hal tersebut memberikan kesan tonal yang kabur karena modulasi yang sangat mendadak.

Frase berikutnya yang muncul adalah penutup untuk bagian B. frase tersebut dibentuk oleh dua motif, dimana motif yang pertama merupakan susunan melodi satu suara dengan penggunaan tangga nada pentatonis G minor dan A minor. Namun, penggunaan tangga nada tersebut tidak dimainkan secara lugu, susunan nada tersebut dimainkan dengan figur dan penyisipan nada tetangga (neighbor note) yang bertujuan untuk memunculkan kesan kromatisisme. Kemudian motif yang kedua disusun oleh dua grup ritmis, grup ritmis yang pertama dibuka oleh akor kemudian grup ritmis yang kedua merupakan repetisi dari grup ritmis yang pertama namun pada nada ke lima dipanjangkan.

Selanjutnya pada bagian coda, disusun oleh empat akor yang berbeda. Tiga akor muncul di awal bagian dan bergerak 
secara paralel membentuk motif pertama. Kemudian satu akor terakhir muncul sebagai motif ke dua yang direpetisi dengan augmentasi jumlah ketukan pada sustain akor terakhir. Pada kasus ini, coda berbentuk kadensial seperti kasus yang sering muncul pada era Klasik.

Temuan-Temuan

Grup ritmis yang sering diulang pada karya ini adalah pola ritmis yang terdiri dari 4 nada sepertiga puluh dua diikuti dengan triol seperenambelasan. Hal tersebut menimbulkan efek seperti ritardando (melambat) karena kesan figur yang semakin renggang. Grup ritmis tersebut muncul pada gerakan 1, 3, dan 4. Meskipun grup ritmis tersebut diolah dengan berbagai macam bentuk, namun esensi dari grup ritmis tersebut tidak hilang, yang terjadi adalah kesan variatif dalam setiap pengolahan.

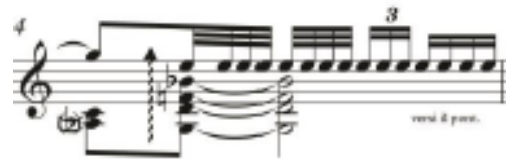

Temuan kedua adalah terdapat kesan kesamaan antara gerakan 1 dengan 3 dan gerakan 2 dengan 4 . Persamaan antara gerakan 1 dan 3 tersebut terdiri dari beberapa aspek, diantaranya kedua gerakan tersebut merupakan bagian lambat dalam keseluruhan karya, meskipun dengan nama gerakan yang berbeda dan dengan tempo yang berbeda. Kemudian untuk kesan kesamaan yang kedua antara gerakan 1 dengan 3 adalah adanya kesan kesamaan pada bagian ending bagian A gerakan tersebut, yaitu melodi bergerak dari register suara atas menuju suara bawah dan pada dua nada terakhir memiliki interval yang sama yaitu interval 1 turun. Interval tersebut dihitung berdasarkan half steps.

Kesan kesamaan lain yang terdapat pada gerakan 1 dan 3 terdapat pada bagian coda. Kemiripan tersebut terdapat pada teknik pengolahan figur dan motif. Pada pengolahan yang pertama, penggunaan akor dengan teknik glissando pada salah satu komponen akor untuk menuju salah satu nada yang akhirnya membentuk akor baru. Pada gerakan 1 keterangan teknik tersebut ditulis dengan "bring out $\mathrm{F}$ to F\#" dan pada gerakan 3 ditulis dengan "glissando". Walaupun penulisan keterangan teknik pada kedua gerakan tersebut berbeda, namun tetap memiliki esensi yang sama. Kesan kesamaan terakhir yang penulis rasakan adalah pengolahan dinamik dan tempo pada motif kedua pada grup ritmis yang terdapat pada coda. Pada pengolahan tempo terdapat kesan ritmis melebar dan pelambatan tempo. Pada gerakan 1, pelambatan tempo ditulis dengan keterangan "poco rall" dan pada gerakan 2 ditulis dengan "rall". Kemudian pada dinamik terdapat dinamik yang berkesan menghilang.

Temuan berikutnya adalah kesan kemiripan gerakan 2 dan gerakan 4 . Gerakan 2 dan gerakan 4 merupakan bagian cepat pada karya El Polifemo de Oro. Pada kedua gerakan tersebut yang pertama memiliki kesamaan pada pola musikal. Pola musikal pada gerakan 2 dan gerakan 4 disusun dengan pola ritmikal. Tema utama dibentuk dengan penekanan-penekanan pada ritmiknya meskipun pada bagian dua tidak terdapat keterangan yang menyatakan tentang pola ritmikal namun dapat dilihat dari struktur tema utama yang berbentuk frase ritmikal.

Kemudian kesamaan kedua pada gerakan 2 dan 4 adalah dalam kedua gerakan tersebut memiliki struktur yang hampir sama, yaitu banyak terdapat bagian-bagian yang repetitif. Pada bagian ending disusun dengan struktur yang hampir sama, yaitu ditutup dengan akor yang diolah dengan kadensial ritmikal. Kesan kesamaan lain yang terdapat pada gerakan 2 dan 4 adalah adanya gerak akor paralel. Pada gerakan 2, gerak paralel tersebut berbentuk broken chord atau bisa disebut dengan arpeggio. Sedangkan pada gerakan 4, gerak akor 
paralel tersebut diolah dengan teknik rasgueado.

\section{Penutup}

Berdasarkan dari penelitian yang telah dilakukan oleh penulis, karya El Polifemo de Oro disusun dengan menggunakan sistem komposisi serial dalam pengolahan frase-frase pada ke-empat gerakannya. Terdapat beberapa frase atau motif yang tidak menggunakan sistem serial, namun masih bersifat atonal. Dalam kasus tersebut, melodi yang tidak menggunakan sistem serial tersebut berperan sebagai codetta, coda, dan menjadi jembatan untuk menuju deret seri yang akan muncul berikutnya. Dari kombinasi di antara penggunaan sistem serial dan sistem atonal non serial dapat disimpulkan bawha karya tersebut menggunakan sistem komposisi serial bebas atau serial campuran yang lebih lazim disebut dengan free serialism system.

Meskipun karya ini bersifat atonal, namun masih terdapat beberapa figur yang memiliki kesan tonal. Kesan tonal tersebut muncul dalam format akor maupun potongan tangga nada. Namun demikian akor dan tangga nada tersebut tidak memiliki peranan pada relasi harmoni musik tonal, sehingga masih bersifat atonal. Akor dan potongan tangga nada muncul dalam berbagai bentuk, yaitu akor-akor minor dan diminished, serta interval M3 yang menjadi identitas akor mayor. Di samping itu juga tangga nada pentatonis dan tangga nada diminished. Hal lain yang menimbulkan kesan tonal adalah bagian yang bersifat ritmikal, didalam bagian tersebut terdapat pengulangan-pengulangan nada seperti akor yang menggunakan teknik broken-chord (arpeggio).

Temuan 48 permutasi deret yang muncul dalam matriks berdasarkan pengolahan deret P4, pada kenyataannya tidak semua deret digunakan dalam penyusunan komposisi. Deret-deret tersebut muncul beragam, baik secara penuh maupun dalam bentuk sebagian (subset). Deret-deret yang muncul adalah P4, P9, I0, I5, R4, dan RI0.

\section{Referensi}

Brindle, Reginald S. 1966. Serial Compotition. Oxford University Press: New York Toronto Brindle, Reginald S. 1982. El Polifemo de Oro. Scott \& Co.ltd: London

Kostka, Stefan. 2006. Material and Techniques of Twentieth-Century Music. Pearson

Education, Inc: New York

Machlis, Joseph. 1963. Introduction to Contemporary Music. J.M. Dent: London

Mark, Dieter. 2009. Sejarah Musik 4. Pusat Musik Liturgi: Yogyakarta

Stein, Leon. 1979. Structure \& Style, The Study and Analysis of Musical Forms. Summy-

Bichard Inc: Miami

Strauss, Joseph N. 2005. Introduction to Post Tonal Theory. Pearson Education, Inc: New York

Whittall, Arnold. 2008. The Cambridge Introduction to Serialism Cambridge introduction to music. Cambridge University Press. 